\title{
Studies for Intervention and Effect Assessment on Arsenism
}

\author{
Yajuan Xia\#, Kegong Wu, Zhiwei Guo, Weihong Yang, Yanhong Li, Jun Liu \\ Inner Mongolia Center for Endemic Disease Control \& Research, Huhhot, China \\ Email: "yajxia@126.com
}

Received May 28, 2013; revised June 30, 2013; accepted July 29, 2013

Copyright (C) 2013 Yajuan Xia et al. This is an open access article distributed under the Creative Commons Attribution License, which permits unrestricted use, distribution, and reproduction in any medium, provided the original work is properly cited.

\begin{abstract}
Chronic exposed to high arsenic via drinking water is worldwide public health problem. A large number of epidemiological studies showed that exposed to arsenic cause the human body skin lesions and also induce cancer, cardiovascular and other kind of diseases. So arsenism not only affect the person's work capability and life quality but also result in economic losses and mental suffering. How to prevent and control the effects of high arsenic? What intervention is more important and necessary for arsenism? How to scientifically assess the interventions effect of short-term and long-term? Through a systematic follow-up investigation in different high arsenic regions in Inner Mongolia, the environmental arsenic and human body internal arsenic exposure were analyzed, the clinical characteristics and signs of arsenism patients were examined. We established the evaluation system of intervention and control measures for population exposed to high arsenic. This evaluation system and control measures included government and exposed population. For government, change water supply and keep it work well and health education is very important. For exposed population, improving the diet and treating the symptoms or signs related to arsenic is more necessary. Arsenic in human body such as nail or urine sample arsenic must be reduced to normal value and this index show that the subject if still or not expose to high arsenic.
\end{abstract}

Keywords: Exposed to Arsenic; Intervention; Assessment

\section{Introduction}

Chronic exposed to high arsenic via drinking water is worldwide public health problem. More than 20 countries in different parts of the world, including China, India and Bengal, have reported that groundwater contained high-arsenic level caused chronic aresenism. A large number of epidemiological studies showed that exposed to arsenic cause the human body skin lesions and also induce cancer, cardiovascular and other kind of diseases [1-4]. So arsenism not only affect the person's work capability and life quality but also result in economic losses and mental suffering. How to prevent and control the effects of high arsenic? What intervention is more important and necessary for arsenism? How to scientifically assess the interventions effect of short-term and long-term? In order to reduce the damage of arsenism, China governments have provided large funds to conduct research on epidemiological investigation, clinic diagnosis and control measurements. In addition to

${ }^{*}$ This work was supported by WHO and Inner Mongolia science and technology bureau.

${ }^{*}$ Corresponding author. changing water in arsenic area, other general preventive measurements have been taken. This paper provides some answers through a systematic follow-up investigation in different high arsenic regions in Inner Mongolia.

\section{Interventions and Control Measures}

According to the epidemiological investigation and results, we conducted a systematic follow-up investigation after taken some intervention and control measures in different high arsenic regions. We analyzed the environmental arsenic and human body internal arsenic, examined the clinical characteristics and signs of arsenism patients, did questionnaire of person's behavior habit changes. The results are as follows.

\subsection{Changing Water Supply, the Arsenic in Drinking Water Is Must Meet to Standard of Drinking Water}

See Table 1. The results show that compare to control area, the population arsenic in urine sample before and 
Table 1. Urine arsenic and changes in different population after stop high-arsenic drinking.

\begin{tabular}{ccc}
\hline Different population & $\mathrm{N}$ & $\begin{array}{c}\text { Mean }(\mathrm{mg} / \mathrm{L}) \\
\text { Urine As }\end{array}$ \\
\hline Control area $(\mathrm{As}<0.03 \mathrm{mg} / \mathrm{L})$ & 26 & $0.021 \pm 0.013$ \\
$\begin{array}{c}\text { High-As village: before changing } \\
\text { water supply }(0.101-0.8247 \mathrm{mg} / \mathrm{L})\end{array}$ & 105 & $0.709 \pm 0.045^{*}$ \\
$\begin{array}{c}\text { After changing water supply } \\
\text { for } 1 \text { year }(\text { As }<0.05 \mathrm{mg} / \mathrm{L})\end{array}$ & 105 & $0.069 \pm 0.053^{*}$ \\
$\begin{array}{c}\text { After changing water supply } \\
\text { for } 6 \text { years }(\text { As }<0.05 \mathrm{mg} / \mathrm{L})\end{array}$ & 105 & $0.029 \pm 0.045$ \\
\hline
\end{tabular}

*Compare to control $\mathrm{p}<0.01$

after changing water supply one year, there is significant difference. But after changing water supply for 6 years there are no difference in urine sample compare to control. This mean if the persons stop drinking high-As water for several years, the urine As will tend to normal. So changing water supply is the most useful control measures.

\subsection{Improving Nutrition and Discharging Arsenic from Body}

Analyzed the epidemiology database, the results show that nail As levels tended to increase with water arsenic concentrations increasing, while nail arsenic levels tend to decrease with nail selenium increasing. See Figures 1 and $\mathbf{2}[5]$.

Does selenium can discharge arsenic from body? We try to give the organic selenium $200 \mu \mathrm{g} /$ day to population for 3 months who still drink high-arsenic water, analyzed the urine arsenic and hair arsenic. The results show that Selenium can discharge the arsenic from the body although the person was still drinking high arsenic water. There is significant difference of urine and hair arsenic between before and after given selenium supplement $(\mathrm{p}<0.01)$. See Table 2 [6].

Although the urine and nail arsenic is normal after population stop drinking high arsenic water for several years, but if we improve their nutrition and give them supplements, how about the result, does can discharge some arsenic from body and combined to cell or organ? We selected some subjects who stop drinking high arsenic water for 6 year and give them Centrum supplements (Wyeth company products, complete from A to Zinc and contain selenium $25 \mu \mathrm{g} /$ pill), 1 pill each day for one month, analyzed the urine and nail arsenic. See Table 3, there is no significant difference after given supplements, but the nail or urine arsenic increased, from the results we can guess if the supplements can accelerate remove the arsenic that combined to cell or organ. So the supplement or diet is an important cofactor to reduce the damage of arsenic.

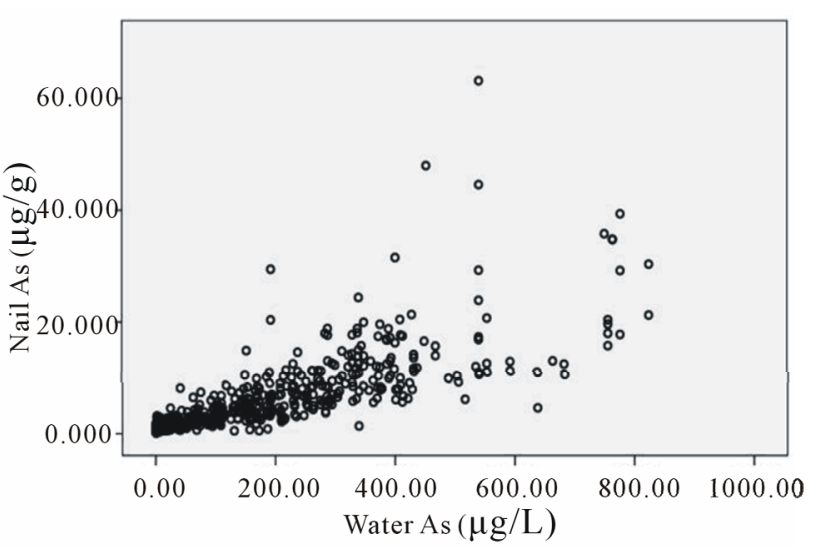

Figure 1. The scatter of water arsenic and nail arsenic.

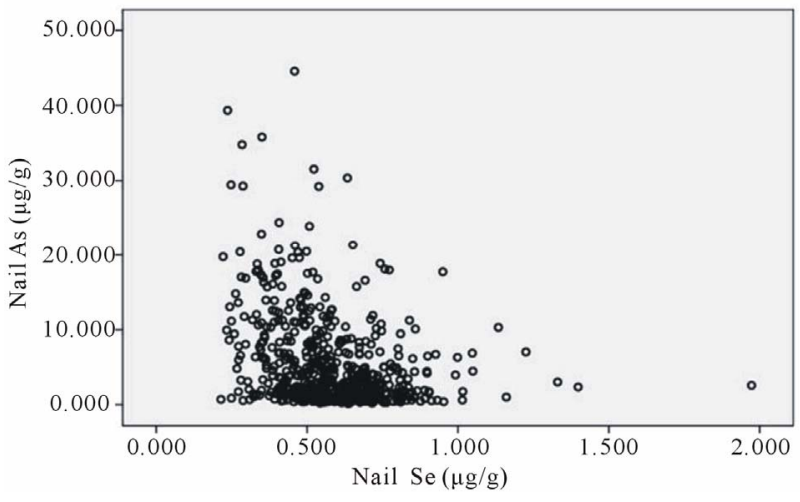

Figure 2. The scatter of nail arsenic and nail selenium.

Table 2. The effect of discharge arsenic from selenium.

\begin{tabular}{cccc}
\hline $\begin{array}{c}\text { Organic } \\
\text { Selenium }\end{array}$ & $\mathrm{N}$ & $\begin{array}{c}\text { Urine As Mean } \\
(\mathrm{mg} / \mathrm{L})\end{array}$ & $\begin{array}{c}\text { Hair As mean } \\
(\mu \mathrm{g} / \mathrm{g})\end{array}$ \\
\hline Before given & 48 & $1.078 \pm 0.085$ & $4.75 \pm 3.25$ \\
After given & 48 & $0.046 \pm 0.031$ & $1.75 \pm 0.98$ \\
\hline $\mathrm{p}<0.01$. & & &
\end{tabular}

\subsection{Treating the Related Symptoms}

There is no specific therapeutic drug for arsenism at the moment, so it is difficult for fully cure the patients. Our clinical investigation showed that even in some places where the water source was changed, the control of arsenism is not satisfactory, the clinical symptoms and signs of only $30 \%$ patients were improved and $52 \%$ patients no change while $18 \%$ patients got worse after intervention [5]. The improvement of symptoms or signs of arsenism subject will take more than one year, so the improvement of symptoms or signs of arsenism is not good indicator in short time. But it still can improve the life quality of patients through some intervention measures and treating the related symptoms or disease caused by arsenic, and the clinical characteristic and signs of patients would be improved [7]. 
Table 3. The results of supplement for population who stop drinking high-As water.

\begin{tabular}{ccc}
\hline & $\mathrm{N}$ & Urine As Mean $(\mathrm{mg} / \mathrm{L})$ \\
\hline Before given supplements & 36 & $0.0195 \pm 0.013$ \\
After given supplements for 3 days (organic selenium ) & 36 & $0.0219 \pm 0.085$ \\
After given supplements for 5 days (organic selenium ) & 36 & $0.0271 \pm 0.031$ \\
After given supplements for 30 days (organic selenium ) & 36 & $0.0238 \pm 0.045$ \\
\hline
\end{tabular}

Urine arsenic: $\mathrm{F}=0.126, \mathrm{P}=0.945, \mathrm{p}>0.05$ : nail arsenic: $\mathrm{t}=1.186, \mathrm{p}=0.244, \mathrm{p}>0.05$.

\subsection{Health Education}

Tell people knowledge about the damage of arsenic and how to reduce the damage whether change water supply or not. Through health education, more persons know the knowledge and they actively try to reduce the damage of arsenic and change their behavior. Table 4 shows the health knowledge awareness rate of population and behavior changes. Such as if the water supply does not changed, the family try to drink the relative lower arsenic water, and they try to improve their nutrition and eat some supplements. The results show health education is more effective intervention measure.

\section{Assessment for the Effects of Intervention and Control Measures}

From our systematic follow-up investigation, we thought the assessment system should be including environmental indicator (water arsenic), human body internal arsenic exposure (urine or nail arsenic), health education effects (awareness rate of health knowledge and behavior change levels) and patients actively treat the symptoms or signs related to arsenic.

\subsection{Assessment for Effects of Short-Term}

Changing water supply and the arsenic meet to standard of drinking water is the most important and effective control measure. Arsenic in human body sample (nail or urine) is a sensitive and rapid indicator that can reflect if the subjects still exposed to high arsenic or not. So the water arsenic and population urine or nail arsenic is the indicators for short-term assessment of intervention and control measures.

\subsection{Assessment for Effects of Long-Term}

Assessment for intervention effects of long-term should be included the assessment for government and exposed subjects.

For government:

1) To ensure the quality of change water, the local government must focus on the long-term management. The most important thing is to arrange the qualification testing laboratory monitor the water quality for two times
Table 4. The effects of health education.

\begin{tabular}{ccc}
\hline Education & $\begin{array}{c}\text { Awareness rate } \\
\text { of health knowledge }\end{array}$ & Behavior changes \\
\hline before & $50.9 \%(55 / 108)$ & $40.74 \%(44 / 108)$ \\
After & $87.96 \%(95 / 108)$ & $74.07 \%(80 / 108)$ \\
\hline
\end{tabular}

Awareness rate: $\chi^{2}=34.909, \mathrm{p}<0.01$; behavior changes $\chi^{2}=24.539, \mathrm{p}<$ 0.01 .

each year (one time for dry season and one time for wet season). If the result is not meet to standard of drinking water, the lab technologist needs to collect sample and test again. If the result is really does not meet to the standard, the local government should find the reasons why and take appropriate measures. If the results are above $0.1 \mathrm{mg} / \mathrm{L}$ in any serial two times, the water supply must stop drinking;

2) Monitoring the arsenic in human body sample (nail or urine). This index can reflect if the low-arsenic water supply works well or not;

3) Health education, tell the population knowledge about the damage of arsenic and how to reduce the damage whether change water supply or not. More persons know the knowledge, the better effect of control. If the water supply does not changed at the moment, the governments should tell the residents which well or water supply is relatively safe.

For exposed subjects:

1) Ask the person improve the diet or take some supplement. Sufficient nutrition is good for reduce the damage of arsenic;

2) Although the improvement of symptoms or signs of arsenism is not good indicator in short time, after take intervention measures for long time, the symptoms or signs related to arsenic will be improve;

3) Ask the patients actively treat the symptoms or signs related to arsenic. It will be relieved the patient's suffering and delayed the occurrence of long-term effects caused by arsenic.

\section{Conclusion}

The assessment and evaluation system of intervention and control measures should be including government and personal efforts and actions. The effect of intervention and control measures should consider the recent time 
and long term. We thought the effects evaluation for long-term intervention is more important and necessary for arsenism control.

\section{REFERENCES}

[1] Y. J. Xia, H. Z. Ma, K. G. Wu, G. J. Yu, Y. X. Qin and H. J. Zhou, "Peripheral Vascular Diseases Caused by Arseism," Chinese Journal of Endemiology, Vol. 14, September 1995, pp. 54-57.

[2] F. J. Luo and Z. D. Luo, "Study on Relationship between High Arsenic Drinking Water and Cancer in Heihe Village of West Hohhot," Chinese Journal of Epidemiology, Vol. 16, No. 5, 1995, pp. 289-291.

[3] J. R. Chen and H. Y. Chiou, "Studies on Relationship between Cardio-Disease and Long-Term Expose to Arsenic in Taiwan," Chinese Journal of Public Health, Vol.
15, No. 3, 1996, pp. 59-67.

[4] H. Y. Chiou and Y. M. Xue, "Epidemiology Study on Relationship between Cancer and Arsenic Exposure," Chinese Journal of Public Health, Vol. 15, No. 3, 1996, pp. 92-108.

[5] Z. W. Gu, K. G. Wu, Y. H. Li, W. H. Yang, X. H. Han and Y. J. Xia, "Study on Relationship between Nail Arsenic-Selenium and Arsenism Clinical Degree for Population Exposed to Arsenic," Chinese Journal of Endemiology, Vol. 26, No. 1, 2011, pp. 10-12.

[6] K. W. Wu, H. Z. Ma, G. J. Yu and Y. J. Xia, "The Study on Intervention to Arsenism," Chinese Journal of Endemiology, Vol. 14, September 1995, pp. 4-7.

[7] X. Y. Xia, Y. H. Li, R. H. Dang and K. G. Wu, "Study on Comprehensive Measures to Prevention and Control Arsenism," Endemic Disease Bulletin, Vol. 18, No. 2, 2003, pp. 62-63. 